objektivering, der enten overhovedet ikke findes eller kun findes deficient hos Sokrates (p.130). Behandlingen af det vanskelige spørgsmål om $\mathrm{Pla}$ tons forståelse af historien munder desværre ud i en balancegang mellem etablerede forskningspositioner, nærmere bestemt mellem Heidelberg og Tübingen, henholdsvis Hans-Georg Gadamer og Konrad Gaiser. Dette er så meget mere ærgerligt, som E.O. allerede gennem den kompositionsorienterede analyse af værket har leveret dokumentation for, at der i Platons tænkning findes et uomgængeligt moment af historisk orientering.

Mens grundene til at kalde indeværende kommentar for et essay var mindre indlysende, er der ingen tvivl om, at E.O. har præsenteret et tankevækkende stykke hermeneutisk arbejde. Kommentaren er værd at læse, ikke bare fordi den udfylder et hul i den hermeneutiske Platonlæsning, der er relativ fattig på fortolkninger af Symposion, men fordi den gør det godt. Desværre tages der ikke højde for det punkt i Symposion, der notorisk sætter grå hår $\mathrm{i}$ hovedet på den hermeneutiske fortolker, nemlig den vanskelige passage om det højeste skue af 'selve det skønne', der hverken er "en slags logos eller en slags epistçmç" (211a). At der skulle være noget ganske centralt for filosofien, der ligger udenfor logos må tage sig temmelig ubehageligt ud for den hermeneutiske fortolkning. Imidlertid kommenterer E.O. stort set ikke dette punkt (p. 103). Det ligger vel ikke uden for hermeneutikkens muligheder at gøre forsøget?

Jakob L. Fink

\section{Til sagen?}

Hans Blumenberg: $Z u$ den Sachen und zurück. Subrkamp Verlag, Frankefurt am Main 2002

Fra Hans Blumenbergs efterladte skrifter udkom i november 2002 en bog med titlen „Zu den Sachen und zurück”. På omslagsteksten introduceres værket af udgiveren, Manfred Sommer, som "...en filosofisk, grundlagning af Blumenbergs projekt om en genuin fanomenologisk antropologi konciperet $i$ modsatning til Heidegger". Den der er bekendt med Blumenbergs tænkning vil vide, at ideen om en fænomenologisk antropologi blev et mere og mere fremherskende motiv i Blumenbergs metaforologiske undersøgelser. De forventninger om en systematisk teoribygning, den fordringsfulde proklamation af et sådant projekt måtte afføde, finder utvivlsomt ikke deres indfrielse i " $Z u$ den Sachen und zurück". Man skal imidlertid ikke have læst meget Blumenberg, før det bliver klart, at sådanne forventninger under alle omstændigheder er malplacerede. Med sin metaforologiske arbejdsform befinder Blumenbergs interesse sig i forgrunden af den filosofiske begrebsdannelse. Hvis ikke en filosofisk teori i gængs forstand, hvad er det imidlertid så, man af Blumenberg kan forvente sig under overskriften "en fænomenologisk antropologi"? 
En ide herom giver " $Z u$ den Sachen und zurück", der ikke fremstår som et gennemkomponeret værk, men som en række tekster om emner der hører Husserls fænomenologi til. Ved første gennemlæsning er det dog ikke altid tydeligt, hvilken sag de forskellige tekster drejer sig om, al den stund at Blumenbergs tilnærmelse til "sagen selv" ikke skyr nogen omvej, der kan forhale dette møde til fordel for den perspektiviske mangfoldighed: "Omvejens vasen er at holde sig til det nu engang valgte mål, men at tillade sig at anvende eller endog bortodsle mere tid i forfolgelsen heraf, end den blotte formailstjenlighed ville krave. Heri bestar lysten ved ekskurser og digressioner, der ikeke er andet end intellektuelle omveje" (p. 270). For Blumenberg er det tvivlsomt, som det andetsteds udtrykkes, om den lige vej imellem to punkter også er den humane vej imellem dem. Om teksternes vanskelighed kan Manfred Sommer således gøre sig følgende notits: "Ikke at spare laserne for komplicerede vendinger og lange veje har forfatteren [dvs. Blumenberg; K.L.] altid betragtet som sin made at udvise dem respekt på." (p. 352). I det følgende skal jeg, i stedet for at opridse de fænomenologiske variationer Blumenberg fornøjer sig og læseren med i det aktuelle skrift, antyde nogle baggrundsmotiver, der måske kan gøre Blumenbergs omveje mere tilgængelige.

I et idehistorisk perspektiv kan man sige, at der i nyere tysk filosofi sker to afgørende tranformationer af Husserls fænomenologi. Dels en transformation af fanomenologien ind $i$ bermeneutikeken, dels en transformation af fanomenologien ind i antropologien. Dominansen af den eksistentialanalytiske "Hermenentik der Faktizität" (Heidegger, 1923) og dens forlængelse i Gadamers hermeneutik gør det ikke svært at udpege den sejrende part, hvis man måler sagen virkningshistorisk. Det gør det imidlertid ikke mindre interessant f.eks. at notere sig følgende to publikationsdata: Martin Heideggers "Sein und Zeit" (1927) og Helmuth Plessners "Die Stufen des Organischen und der Mensch" (1928). M.a.o.: omtrent samtidig med Heideggers hovedværk, udgiver Husserleleven Helmuth Plessner sit antropologiske hovedværk, der i sin programmatik eksplicit stiller sig i opposition til Heidegger. Det ville sikkert ikke være ufordelagtigt at se Blumenbergs tænkning bl.a. på denne idehistoriske baggrund - hvad der dog her kun kan stå som en formodning. Under alle omstændigheder er fænomenologien født med, hvad man med Blumenberg kunne kalde en antropologifobi. Denne fobi gjaldt ikke blot fænomenologiens grundlægger, for hvem fænomenologien vandt sin strenge videnskabelighed gennem en afsked med enhver form for naturalisme. Den gjaldt også fænomenologiens "mest betydelige hæretiker" for hvem det, der tog sig ud som en antropologi, og også blev læst som en sådan (i skuffelse og med stor beklagelse, bl.a. af Husserl), blot var en tilgang til det, det egentlig kom an på, nemlig en ud- 
arbejdelse af værensspørgsmålet. For Blumenberg gælder det imidlertid om at redde dette antropologiske potentiale fra den gnostiske usurpation, det tendentielt udsættes for allerede hos den tidlige Heidegger, men først fuldt ud hos den sene. At der var gnostiske tendenser hos Heidegger var allerede blevet lokaliseret af Hans Jonas, hvis værk "Gnosis und Spätantike Geist" (1934/1954) har stor betydning for Blumenberg. Omdrejningspunktet for Blumenbergs "Auseinandersetzung" med Heidegger kan man bl.a. fiksere vha. Heideggers begreb om "Sorge", der som et antropologisk strukturprincip er funktionsækvivalent med Blumenbergs begreb om selvopretholdelse ("Selbsterbaltung"). Mens Sorgestrukturen hos den tidlige Heidegger havde været indifferent mht. dens to mulige modifikationer - uegentligheden og egentligheden - kan man forstå den sene Heidegger således, at det er selve Sorgestrukturen, der nu forekommer uegentlig. At Sorgestrukturen implicerede, at $\mathrm{Da}-$ sein "zunächst und zumeist" var forfalden til "das Man", var klart allerede i "Sein und Zeit". Imidlertid beroede en omvendelse til egentligheden her ikke alene på noget, som var radikalt "unverfügbar". Ganske vist var angsten og kaldet noget, der tildrog sig, men kun som muligheden af en egentlighed, der, for at blive til virkelighed, krævede Daseins beslutsomme selvovertagelse. Man kan heri se en rest af myndighed. For Heidegger forekom "Sein und Zeit" imidlertid som "endnu for subjekti- vistisk". Konversionen fra uegentlighed til egentlighed var for den sene Heidegger derfor ikke længere et spørgsmål om "Entschlossenheit", men om "Ereignis". Menneskets fortabelse til værensglemslen var nu så radikal, at enhver konversion ("Kehre") alene kunne udgå fra væren. Mens Husserl havde insisteret på, at mennesket selv skulle varetage sin konversion - hos Husserl fra den naturlige indstilling til den transcendentalfænomenologiske - fandt fænomenologien sin direkte modposition i Heideggers værenshistoriske spekulationer. I stedet for varetagelse (alias cura eller Sorge) var konversion et spørgsmål om tildragelse. Herimod sætter Blumenberg tanken om selvopretholdelse og satser dermed på den nyere tids bestyrkelse af subjektiviteten gennem identifikationen af selvopretholdelse og rationalitet. Mennesket er det væsen, der ikke kan overgive sig til transitiv opretholdelse, men refleksivt må sørge for sig selv, dvs. myndigt føre sit liv.

Hvad der gør Blumenberg mere sympatisk stemt overfor Husserl end Heidegger er, at intimiteten imellem selvopretholdelse og fornuft her fastholdes. For Blumenbergs transformation af fænomenologien ind $i$ antropologien betyder det nærmere bestemt, at fænomenologiens kardinalbegreb, intentionaliteten, bliver indbegrebet af de former, hvormed mennesket skaber distance til en absolutistisk virkelighed og dermed varetager dets egen opretholdelse. 
Intentionalitet er et system af ydelser - med Cassierer: symbolske former - der kompenserer for fraværet af en umiddelbar tilpasning og derved dxmmer op for den "Reizüberflutung" (Gehlen), der truer det verdensåbne menneske med desorientering og betydningstab. I overensstemmelse med Husserl anser Blumenberg i den forbindelse tidsbevidstheden for at være en så fundamental intentionalitetsform, at intentionalitet uden tidsbevidsthed slet og ret er umulig. "Tiden er den form, hvormed bevidstheden qua intentionalitet realiserer sig. Intentionalitet betyder, at jeg har at gore med det og er rettet imod det, som jeg ikke. selv er." (p. 122). Tidsbevidstheden er betingelsen for, at intentionaliteten ikke falder sammen med den sag, den er rettet imod, og er som sådan betingelse for intentionalitetens opretholdelse. Manfred Sommer, hvis studier i fænomenologien kan forstås som en eksplikation af Blumenbergs fænomenologikonception, har udtrykt det på følgende vis: "At have tid befordrer selvopretholdelsen, og for sa vidt er tiden selv okonomisk. Den tillader os nemlig at omforme det meget, som vi ikke kan overkomme pà en gang, i et mindre, som vi kan forarbejde fortlobende: $i$ stedet for $p a$ en gang noget der er for stort, flere gange efter binanden noget overkommeligt smàt." (Eviden₹ im Augenblick. Frankfurt am Main 1987, p. 181). Intentionaliteten kan, trods sin uendelige verdensappetit, ikke besidde alt på engang. Diskursivt må den lade verden strømme igennem sig, og lade sine genstande klinge ud i dets præsensfelts retentionale og protentionale udstrakthed. Betingelsen for at have en verden er tidsligheden - i kort form: "Die Welt kostet Zeif". Intentionalitetens iboende stræben efter at besidde hele sagen og ikke blot et udvalg af aspekter er en antinomi i intentionaliteten, al den stund at dette kravs indfrielse ville føre til intentionalitetens sammenbrud. Taber intentionaliteten sin tidslighed, mister den det centrum, som den excentrisk (Plessner) sørger for og dermed også den verden, som ikke blot omgiver den, men som den i emfatisk forstand har. Virkeliggøres utopien, taber mennesket verden - fiat utopia, pereat mundus. Fra dette punkt udgår Blumenbergs betænkelighed ved Husserls mere programmatiske ytringer, for så vidt disse går $\mathrm{i}$ retning af en sådan utopisme. Hvad Husserl under stikordet teknik beklager som et meningstab og en heraf følgende krise, ser Blumenberg som et rationelt afkald på mening. At vi ikke er ved sagen selv, men ved tekniske representationer og institutioner - foreløbige begreber der holder pladsen for mulig anskuelse, indstiftede traditioner, regulationer og delegationer der aflaster mennesket fra hver gang at skulle begynde forfra etc. - er rationelt af selvopretholdelsesgrunde. Hvad der kan konstateres er sådan noget som en "Ökonomie des Bewußtseins", der består i "...at lade det vare nok med min dre end sagen se lv og med be le sagen." (p. 150).

Titlen " $Z u$ den Sachen und zurück" 
er sigende for Blumenbergs fænomenologi. Mens både Husserl og Heidegger er interesseret $i$,,sagen selv", ganske vist med den betydelige forskel at vi hos førstnævnte selv skaffer os adgang til sagen, mens vi hos sidstnævnte andægtigt er henvist til værens eventuelle gunst, så forskyder Blumenberg interessen hen imod spørgsmålet om, hvor vi kom fra, inden vi eventuelt måtte komme til „sagen selv“. At vi her ikke har „sagen selv", betyder imidlertid ikke, at vi ikke har sagen, men blot at vi kun har den i dens uendelige variationer, i dens omstændelige fænomenologiske omskrivninger, indspundet $\mathrm{i}$ dens horisonter, historier og digressioner, i dens symbolske former, i dens hermeneutiske receptioner og metaforiske repræsentationer - men ikke selv. Om dette "kun" er et beklageligt deficit eller en human gevinst, er det spørgsmål, hvor vandene skilles. Herom skriver Blumenberg: 'Det realistiske recidiv er formentlig ubandigt, en fristelse, der sågar optrader på filosofiens sublime bojder: Husserls >til sagen selv! $<$ var uden tvivl ligeså passende som farligt. Passende $i$ slutningen af det arrbundrede, der til det yderste havde gjort sig nogternt ved de store systemer og deres relikter; farligt som et lofte om en umiddelbar omgang med realiteuden deres begreb." (p. 238).

Kasper Lysemose

\section{Det meningsfulde liv - re- loaded}

Det meningsfulde liv, red. Cecilie Eriksen, Aarbus Universitetsforlag 2003, 316 sider, $198 \mathrm{kr}$.

Det er først og fremmest individualismen og individualismens manifestationer såsom endeløs selvudvikling og oplevelsesfetichering, der udfordres af kritisk refleksion i antologien Det meningsfulde liv. Herligt forfriskende! $\mathrm{Og}$ ikke mindst tiltrængt med fagligt kvalificerede bud på mening og det menneskelige liv, som kan udgøre et alternativ til personligheds- og selvudviklingsindustriens selvsving, som også med et Ulrich Beck udtryk benævnes svarindustrien $i$ antologien.

Unge forskere fra forskellige akademiske discipliner som litteratur, psykologi, filosofi, lægevidenskab, teologi, naturvidenskab og samfundsvidenskab giver $i$ antologien deres bud på, hvorledes man kan tale om det meningsfulde liv ud fra deres respektive fagtraditioner. Overordnet fortjener projektet uden tvivl ros. Det fremgår klart, efter en gennemlæsning af introduktionen til antologien, som er forfattet af Cecilie Eriksen (cand. mag. i filosofi, AU) og Svend Brinkmann (cand. psych. og ph.d.-studerende ved Psykologisk institut, AU), at ansporingen til projektet om Det meningsfulde liv er at finde i den "peek \& rush"-oplevelseskultur, som forfatterne mener at befinde sig $i-o g$ som de mener, er stærkt problematisk. For 